\title{
The Catabolic Action of Insulin in the Brain Is Mediated by Melanocortins
}

\author{
Stephen C. Benoit, ${ }^{1}$ Ellen L. Air, ${ }^{1}$ Lique M. Coolen, ${ }^{2}$ Richelle Strauss, ${ }^{1}$ Alana Jackman, ${ }^{3}$ Deborah J. Clegg, \\ Randy J. Seeley, ${ }^{1}$ and Stephen C. Woods ${ }^{1}$ \\ Departments of ${ }^{1} P$ sychiatry and ${ }^{2} \mathrm{Cell}$ Biology, Neurobiology, and Anatomy, University of Cincinnati, Cincinnati, Ohio \\ 45267, and ${ }^{3}$ Procter \& Gamble Pharmaceuticals, Mason, Ohio 45040
}

\begin{abstract}
Like leptin, the pancreatic hormone insulin is an important adiposity signal to the brain. We report that the hypothalamic melanocortin system is an important target of the actions of insulin to regulate food intake and body weight. Hypothalamic neurons expressing insulin receptors were found to coexpress the melanocortin precursor molecule pro-opiomelanocortin (POMC), and administration of insulin into the third cerebral ventricle of fasted rats increased expression of POMC mRNA.
\end{abstract}

Body weight is regulated by a complex interaction of peripheral signals with central pathways that influence food intake and energy expenditure. Understanding the high degree of accuracy displayed by most mammals to maintain energy balance is fundamental to our knowledge of how homeostatic systems function, as well as to the etiology and treatment of clinical syndromes, including obesity and eating disorders. One afferent signal to the brain that provides information about the amount of stored calories in the form of adipose tissue is the pancreatic hormone insulin. The secretion of insulin from the pancreas and its level in the blood are directly proportional to adipose mass (Bagdade et al., 1967), such that plasma insulin increases during periods of positive energy balance and decreases during periods of negative energy balance (Bagdade et al., 1967; Woods et al., 1974). Moreover, insulin passes through the blood-brain barrier via a saturable, receptor-mediated process that yields insulin levels in the CNS that are proportional to plasma insulin (Baura et al., 1993).

The administration of exogenous insulin in small amounts into either the neuropil of the ventral hypothalamus or the adjacent third ventricle results in dose-dependent decreases in food intake (Woods et al., 1979; Schwartz et al., 1992) and sustained weight loss that is not attributable to incapacitation or illness (Chavez et al., 1995), and this has been observed in several species. Conversely, the central administration of insulin antibodies results in increased food intake and body weight (McGowan et al., 1992). Consistent with this, the selective removal of insulin receptors from neurons or else the selective absence of key insulin receptor signaling molecules in the brain results in increased body weight and susceptibility to diet-induced obesity (Brüning et al., 2000; Stubdal et al., 2000). Hence, insulin provides a negative feedback

Received March 8, 2002; revised July 12, 2002; accepted July 12, 2002.

This work was supported by grants from the National Institutes of Health and the American Diabetes Association (Physician Scientist Training Award to E.L.A.) and funds from Procter \& Gamble Pharmaceuticals.

Correspondence should be addressed to Stephen C. Benoit, Department of Psychiatry, University of Cincinnati, College of Medicine, Box 670559, Cincinnati, OH 45267-0559. E-mail: stephen.benoit@uc.edu.

Copyright (C) 2002 Society for Neuroscience 0270-6474/02/229048-05\$15.00/0
Finally, a subthreshold dose of the melanocortin antagonist SHU-9119 prevented the reduction in food intake caused by third-ventricular insulin administration. These data suggest that the hypothalamic melanocortin system mediates the anorexic effects of central insulin, as well as of leptin.

Key words: insulin; melanocortins; POMC; food intake; obesity; leptin signal to the CNS that is proportional to peripheral energy stores and is linked to CNS systems that control food intake and body weight.

Like insulin, the more recently characterized adipocyte hormone leptin also acts to reduce food intake and body weight. The central mechanisms of this hormone, however, have been well characterized during the last several years. Considerable evidence now implicates the hypothalamic melanocortin system in the mediation of the anorexic effects of leptin. We hypothesized that the hypothalamic melanocortin system also mediates the central effects of insulin to reduce food intake and body weight. This hypothesis makes several predictions that we tested. First, insulin receptors exist on $\alpha$-melanocyte-stimulating hormone ( $\alpha$ $\mathrm{MSH}$ ) producing neurons within the arcuate nucleus (ARC) of the hypothalamus. Second, insulin stimulates expression of the $\alpha$-MSH precursor pro-opiomelanocortin (POMC). Third, the ability of insulin to reduce food intake depends on melanocortin receptor activation.

\section{MATERIALS AND METHODS}

\section{Subjects}

Subjects for all experiments were male, Long-Evans rats (250-300 gm) individually housed in plastic tub cages. All animals had ad libitum access to water and Purina 5001 rat chow unless otherwise noted.

\section{Experiment 1: dual-labeling immunohistochemistry}

Experiment 1 assessed the hypothesis that insulin receptors are located on hypothalamic arcuate neurons that express the melanocortin precursor POMC. To assess this hypothesis, we used qualitative dual-labeling immunohistochemistry for insulin receptors and POMC.

Procedures. Five rats were given an overdose of pentobarbital (60 $\mathrm{mg} / \mathrm{kg}$ ) and perfused transcardially with $450 \mathrm{ml}$ of $4 \%$ paraformaldehyde in $0.1 \mathrm{M}$ sodium phosphate buffer (PB). Brains were removed, postfixed ( $1.5 \mathrm{hr}$ at room temperature), and stored in $20 \%$ sucrose in PB. Coronal sections were cut $(40 \mu \mathrm{m})$ with a cryostat (Leica, Nussloch, Germany) and stored in cryoprotectant (30\% sucrose and 30\% ethylene glycol in 0.1 M PB) (Watson et al., 1986) at $-20^{\circ} \mathrm{C}$ until further processing for POMC and insulin receptor- $\beta$. Available antibodies recognizing these antigens were all raised in rabbit. To eliminate the possibility of cross-reactivity, a modification of a recently described protocol was used (Hunyady et al., 
1996). Free-floating sections were incubated overnight at $4^{\circ} \mathrm{C}$ with polyclonal antiserum recognizing insulin receptor- $\beta$ (Santa Cruz Biotechnology, Santa Cruz, CA) diluted 1:1000 in incubation solution (PBS containing $4 \%$ normal donkey serum and $0.1 \%$ Triton X-100). Sections were subsequently exposed to biotin-conjugated donkey anti-rabbit IgG (1:400 in incubation solution for $60 \mathrm{~min}$; Jackson ImmunoResearch, West Grove, PA), avidin-biotin-horseradish peroxidase (ABC Elite, 1:1500 in PBS for $60 \mathrm{~min}$; Vector Laboratories, Burlingame, CA), biotinylated tyramide (1:250 for 10 min; Tyramide Signal Amplification; NEN, Boston, MA), and CY3-conjugated streptavidin (1:400 in PBS for $30 \mathrm{~min}$; Jackson ImmunoResearch). Sections were then incubated overnight at room temperature in polyclonal antiserum recognizing POMC (1:1000 in incubation solution; Phoenix Peptides, Belmont, CA) and in Alexa488conjugated goat anti-rabbit (1:400 for $30 \mathrm{~min}$; Molecular Probes, Eugene, OR). Sections were mounted on glass slides and coverslipped with Gelvatol, containing an anti-fading agent [1,4-diazabicyclo $(2,2)$ octane].

Immunocytochemical controls included omission of primary antibody or preabsorption of diluted antiserum with nanomolar concentrations of appropriate purified peptides at $4^{\circ} \mathrm{C}$ for $24 \mathrm{hr}$. In addition, controls included omission of second primary antibody and application of Alexa488-conjugated secondary antibody. Fluorescent-stained sections were examined with a Zeiss (Oberkochen, Germany) laser-scanning confocal microscope system (Zeiss LSM510). Alexa 488 fluorescence was imaged with a $505 \mathrm{~nm}$ emission filter and an argon laser $(488 \mathrm{~nm})$ and visualized as red signal; CY3 fluorescence was imaged with a $567 \mathrm{~nm}$ emission filter and a HeNe laser (544 nm) and visualized as green signal. Images were imported into Adobe Systems (San Jose, CA) PhotoShop 6.0 and Microsoft (Seattle, WA) Word to comprise Figure 1. Images were not adjusted or altered in any way, except for occasional adjustment of brightness.

\section{Experiment 2: POMC expression}

Experiment 2 determined whether administration of central insulin increases expression of POMC mRNA.

Surgeries. With the aid of a stereotaxic device, a stainless steel 21 gauge cannula was implanted $2.2 \mathrm{~mm}$ posterior to bregma, $7.5 \mathrm{~mm}$ below the dural surface and directly along the midline, with bregma and lambda at the same vertical coordinate. The cannula was anchored to the skull with screws and dental acrylic. All rats were allowed to recover for 1 week. Cannula patency was then assessed by injection of $10 \mathrm{ng}$ of angiotensin-II (1 $\mu$ l injection). Cannulas were considered patent if rats consumed $5 \mathrm{ml}$ of water within $1 \mathrm{hr}$ of injection.

Procedures. Beginning at lights-on, each rat received an intrathird ventricular (i3vt) injection $(1 \mu \mathrm{l})$ of either saline or $4 \mathrm{mU}$ of insulin $(n=$ 7 per group). The injections were repeated every $12 \mathrm{hr}$ over a $72 \mathrm{hr}$ period (seven injections total), during which time the rats were food deprived. An additional group of rats $(n=7)$ also received i3vt saline but remained fed ad libitum.

POMC $m R N A$ quantification. Two hours after the final injection, the rats were killed, and the brains were collected. RNA was isolated from whole hypothalami using Tri-Reagent (Medical Research Council, Cincinnati, $\mathrm{OH}$ ) according to the instructions of the manufacturer. DNA contamination was eliminated using a removable DNase system (DNAfree; Ambion, Austin, TX). The absence of DNA contamination was confirmed by amplification of glyceraldehyde-3-phosphate dehydrogenase (GAPDH) (250 ng of RNA per well) with and without a preceding reverse transcriptase (RT) step $\left(2 \mathrm{~min}\right.$ at $50^{\circ} \mathrm{C}$ and $30 \mathrm{~min}$ at $\left.60^{\circ} \mathrm{C}\right)$. Completion of 40 amplification cycles (i.e., $5 \mathrm{~min}$ at $95^{\circ} \mathrm{C}$ for one time; 20 sec at $94^{\circ} \mathrm{C}$ and $60 \mathrm{sec}$ at $62^{\circ} \mathrm{C}$ for 40 times) without detecting a product in the non-RT wells indicated that the RNA samples were not contaminated.

POMC expression was analyzed using the Taqman real-time PCR system (PE Applied Biosystems, Foster City, CA) (Medhurst et al., 2000). POMC was amplified, as above, in triplicate samples of RNA from each rat $(10 \mathrm{ng} / 20 \mu \mathrm{l}$ reaction) using forward and reverse primers (5'-CGCCCGTGTTTCCA-3' and 5'-TGACCCATGACGTACTTCC$3^{\prime}$, respectively; $300 \mathrm{~nm}$ each) coupled with a fluorescent-labeled Taqman probe (6-FAM-ACGGAGATGAACAGCCCTTGACT-TAMRA; 150 nM). GAPDH served as the reference gene in each multiplexed reaction (forward primer, 5'-TGCACCACCAACTGCTTAG-3'; reverse primer, 5'-GGATGCAGGGATGATGTTC-3', 80 nM each; probe VICCAGAAGACTGTGGATGGCCCCTC-TAMRA, $100 \mathrm{~nm}$ ). Reactions were run using the Taqman EZ RT-PCR core reagent kit at the recommended concentrations, although reaction volume was reduced to $20 \mu \mathrm{l}$. Standard curves consisted of pooled RNA from each treatment group in singleplex GAPDH reactions. All reactions completed 40 replication cycles.

Sequence amplification and fluorescence detection were done using the ABI PRISM 7700 Sequence Detection System (PE Applied Biosystems). Baseline fluorescence was determined by the system and defined as the average fluorescence detected during cycles 3-15. The threshold fluorescence was then calculated by the system to be the level of fluorescence that was statistically different from baseline (i.e., 10 times the mean SD of fluorescence in all wells over baseline cycles). Relative expression was calculated based on the cycle number at which the fluorescence exceeded the threshold of detection (CT). Specifically, the CT for GAPDH was subtracted from that of POMC for each well $(\Delta \mathrm{CT})$. The average $\Delta \mathrm{CT}$ for each experimental group was derived from the average $\triangle \mathrm{CT}$ of each rat in that group. The percentage of change in POMC expression, relative to the reference fed saline group, was defined

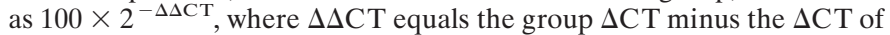
the fed saline group. Percentage of change data were analyzed with one-way ANOVA, which yielded a significant main effect of treatment $\left(F_{(2,19)}=7.44 ; p<0.05\right)$.

\section{Experiment 3: food intake}

Experiment 3 determined whether a subthreshold for feeding dose of a melanocortin antagonist would block the ability of central insulin to reduce food intake.

Surgeries. Intracerebroventricular cannulations were performed as described for experiment 2 .

Procedures. The dose of SHU-9119 (Phoenix Peptides) was $0.1 \mathrm{nmol}$, which has been found previously to be subthreshold for augmenting food intake but nonetheless blocks the anorexic effects of involuntary overfeeding (Hagan et al., 1999). Food was removed $4 \mathrm{hr}$ before the dark phase, and all infusions were administered $1 \mathrm{hr}$ before lights-off. Food was returned at the onset of dark, and intake was measured after 1, 2, 4, and $24 \mathrm{hr}$. Body weights were recorded at $24 \mathrm{hr}$. This design included four within-subjects tests: saline $\rightarrow$ saline, SHU-9119 $\rightarrow$ saline, saline $\rightarrow$ insulin, and SHU-9119 $\rightarrow$ insulin. Order of test infusions was counterbalanced via Latin-square design, with $2 \mathrm{~d}$ between treatments.

\section{RESULTS}

\section{Experiment 1: dual-labeling immunohistochemistry}

We assessed the hypothesized overlap in distribution of POMC and the insulin receptor ( $\beta$-subunit) by qualitative dual-labeling immunohistochemistry. First, immunoreactivity for insulin receptor- $\beta$ was present in brain areas found previously to contain mRNA or binding sites (Baskin et al., 1983), including hippocampus and arcuate nucleus (Fig. 1). No insulin receptor- $\beta$ immunoreactivity was observed in areas of the brain that do not express insulin receptor mRNA. Second, in all sections observed, arcuate neurons with POMC immunoreactivity also had immunoreactivity for the insulin receptor- $\beta$. Figure 1 depicts a representative section with colocalization of POMC and insulin receptor- $\beta$ immunoreactivity in the arcuate nucleus at bregma $-2.4 \mathrm{~mm}$. Extensive colocalization of POMC and insulin receptor- $\beta$ was observed throughout the nucleus in both medial and lateral arcuate neurons. Most ( $\sim 90 \%)$ of the cells with POMC immunoreactivity also had insulin receptor- $\beta$ immunoreactivity. However, not all insulin receptor- $\beta$-immunopositive neurons coexpressed POMC immunoreactivity. Cells positive only for insulin receptor- $\beta$ were distributed throughout the arcuate but primarily observed in the most rostral sections. Furthermore, immunocytochemical controls demonstrated specificity of the primary antibody. Both omission of the primary antibody and preabsorption in diluted antiserum blocked insulin receptor- $\beta$ immunoreactivity.

\section{Experiment 2: POMC expression}

To test the hypothesis that insulin upregulates POMC expression in the ARC, insulin was administered into the third ventricle of fasted rats, and POMC expression compared with fasted, salinetreated, and ad libitum fed rats was measured in whole hypotha- 

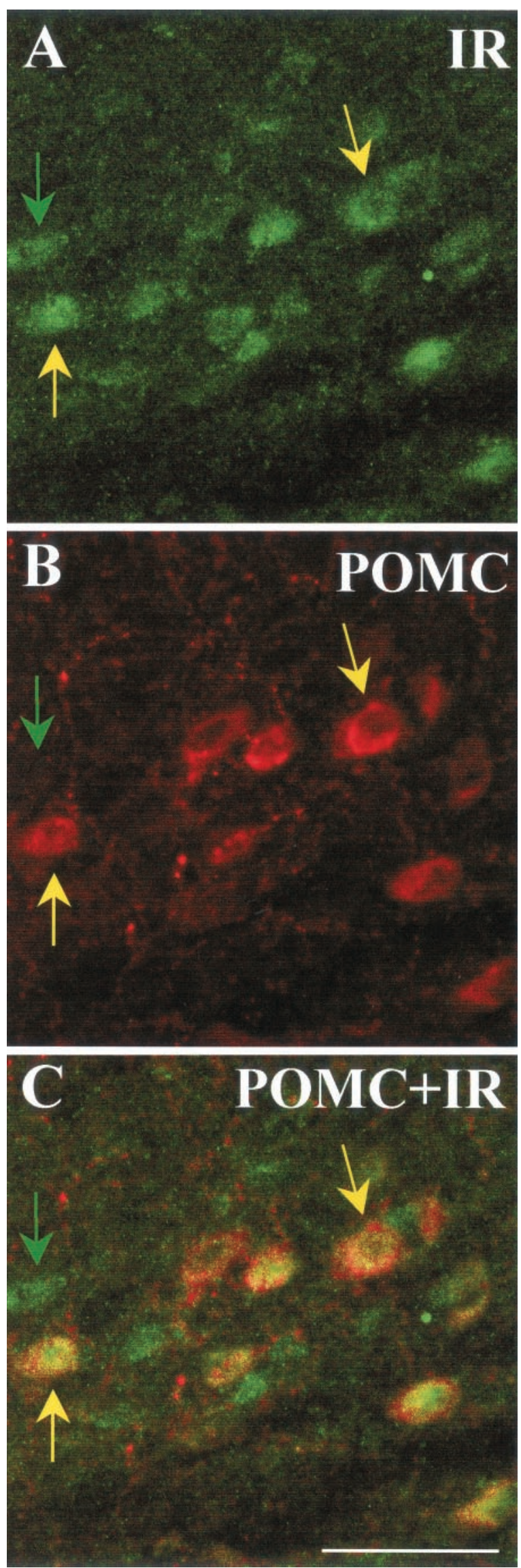

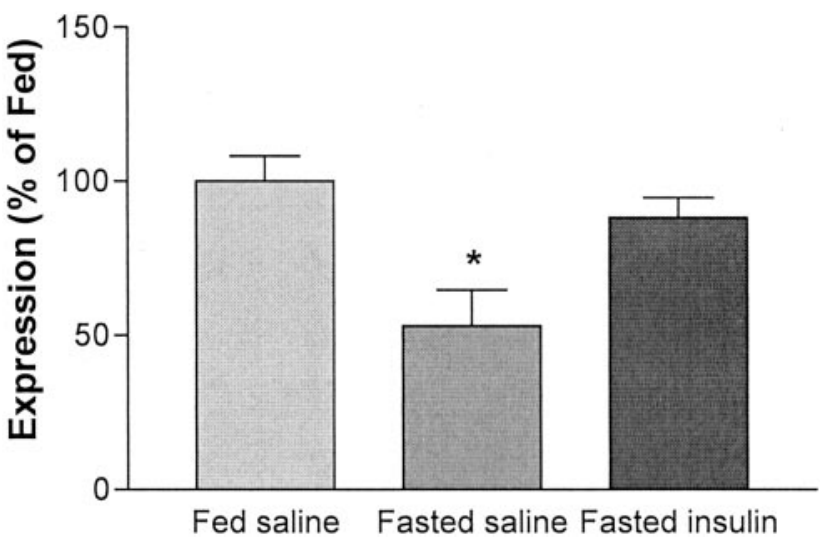

Figure 2. Hypothalamic POMC expression. POMC expression after ad libitum feeding (left bar), a $72 \mathrm{hr}$ fast (middle bar), and a $72 \mathrm{hr}$ fast with i3vt infusions of $4 \mathrm{mU}$ of insulin every $12 \mathrm{hr}$ (right bar). Central administration of insulin increased expression of POMC relative to fasting, and the resultant levels were not different from those that occurred during ad libitum feeding. ${ }^{*} p<0.05$.

lamic extracts by real-time PCR (Medhurst et al., 2000). As depicted in Figure 2, POMC expression in the fasted salinetreated rats was decreased by 50\% (ANOVA; Tukey's post hoc test; $p<0.01$ ) relative to those in a group of fed rats, an effect similar to that seen in previous reports (Schwartz et al., 1997; Thornton et al., 1997; Mizuno et al., 1998). In contrast, POMC expression in insulin-treated fasted rats was significantly higher than that of the level in the fasted saline rats (Tukey's post hoc test; $p<0.05$ ) and not significantly different from the level in the fed controls. Hence, the local administration of insulin greatly attenuated the reduction of ARC POMC caused by fasting. Percentage of change data were analyzed with one-way ANOVA, which yielded a significant main effect of treatment $\left(F_{(2,19)}=\right.$ 7.44; $p<0.05)$.

\section{Experiment 3: food intake}

SHU-9119 in the absence of insulin had no effect on food intake at this dose (Fig. 3), nor did it block the anorexic action of glucagon-like peptide-1 (Seeley et al., 1997). Insulin by itself caused a significant reduction of food intake (Tukey's post hoc test; $p<0.05$ ), and this was completely reversed by the presence of SHU-9119. Food intake data were analyzed with a repeatedmeasures ANOVA, yielding a significant main effect of treatments $\left(F_{(3,12)}=3.52 ; p<0.05\right)$.

\section{DISCUSSION}

Although the importance of insulin as an adiposity signal has been well established, the mechanisms by which it regulates intake and body weight have been ill defined. The central action of insulin to reduce food intake is similar in many ways to what is known about the central action of the adipocyte hormone leptin. Like insulin, leptin secretion and levels in the circulation are directly proportional to adiposity; like insulin, leptin penetrates

\section{$\leftarrow$}

Figure 1. Dual-label immunohistochemistry for insulin receptor- $\beta$ and POMC. The top two panels are confocal images (5 $\mu \mathrm{m}$ optical section) of ARC neurons. Positive immunoreactivity for the insulin receptor- $\beta$ is depicted in green $(A)$, whereas POMC-positive immunoreactivity is depicted in red $(B)$. $C$, An overlay of the above images. Green arrows point to single-labeled neurons; yellow arrows indicate dual-labeled neurons. Scale bar, $50 \mu \mathrm{m}$. 


\section{4-hr Food Intake}

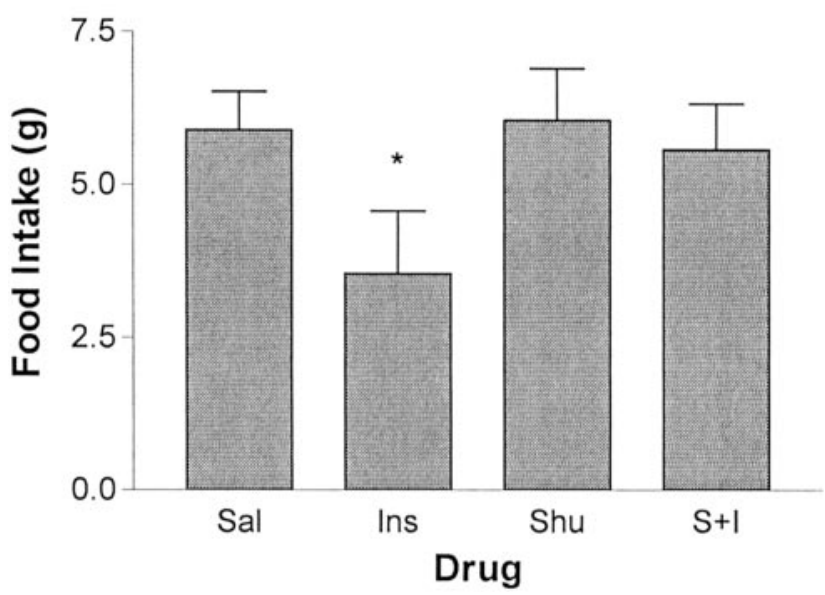

Figure 3. Effect of insulin and SHU-9119 on food intake. Mean $4 \mathrm{hr}$ food intake (in grams) after i3vt administration of saline ( $\mathrm{Sal}$ ), insulin $(8 \mathrm{mU})$ (Ins), SHU-9119 (0.1 nmol) (Shu), and SHU-9119 followed by insulin $(S+I)$. SHU-9119, by itself, had no effect on food intake, whereas insulin significantly reduced intake relative to saline. Administration of SHU9119 before administration of insulin blocked the effect of insulin to reduce food intake $\left({ }^{*} p<0.05\right)$.

the blood-brain barrier via a receptor-mediated process, and, as occurs with insulin, experimentally or genetically induced increases in central leptin activity cause a net catabolic response, whereas decreases cause a net anabolic response (Woods et al., 1998; Schwartz et al., 2000). Hence, insulin and leptin share many common activities regarding the control of energy homeostasis, and recent evidence suggests that they also share common intracellular signaling pathways (Bjorbaek et al., 1998; Barsh et al., 2000; Emanuelli et al., 2000; Niswender et al., 2001). Based on all of this evidence, we hypothesized that insulin and leptin act in concert in the CNS to regulate caloric intake and expenditure.

Considerable evidence suggests that specific neuronal populations in the ARC of the hypothalamus mediate the catabolic action of leptin (Cheung et al., 1997; Fan et al., 1997; Seeley et al., 1997; Thornton et al., 1997; Mizuno et al., 1998). In particular, one population of ARC neurons expresses POMC, the precursor molecule of $\alpha$-MSH. In the CNS, $\alpha$-MSH interacts with melanocortin 3 and 4 (MC3 and MC4) receptors, and administration of $\alpha$-MSH or other MC3/4 agonists reduces food intake and body weight (Fan et al., 1997; Thiele et al., 1998). Consistent with this, overexpression or pharmacological administration of MC3/4 antagonists increases food intake and body weight (Fan et al., 1997; Ollmann et al., 1997; Hagan et al., 2000), whereas genetic disruption of either POMC or the MC4 receptor results in a phenotype that includes increased food intake and obesity (Huszar et al., 1997; Yaswen et al., 1999).

Leptin receptors are expressed by POMC neurons in the ARC (Cheung et al., 1997), and leptin administration stimulates POMC gene expression (Schwartz et al., 1997; Thornton et al., 1997; Mizuno et al., 1998) and increased electrical activity in these neurons (Cowley et al., 2001). Most importantly, melanocortin receptor blockade inhibits the ability of leptin to alter neuronal activation in the paraventricular nucleus and to reduce food intake (Seeley et al., 1997). Based on the reliance of leptin on an intact ARC POMC- $\alpha$-MSH system for its catabolic action and other parallels of insulin and leptin as adiposity signals to the brain, we hypothesized that insulin likewise interacts with the central melanocortin system to exert its effects on energy balance. Consistent with this hypothesis, insulin receptors would be expected to be located on POMC neurons. This was found to be the case (Fig. 1). Moreover, some insulin receptor-containing cells did not contain POMC, indicating that these cells may contain other important ARC systems, such as neuropeptide $\mathrm{Y}$ and agouti-related protein AgRP. These data provide the first demonstration of a direct anatomical link between central insulin receptors and a specific neuropeptide system that regulates energy homeostasis.

One potential way in which insulin may influence the melanocortin system is through regulation of POMC expression. Insulin, at doses that do not influence peripheral glucose levels, was able to attenuate significantly the reduction in POMC expression that accompanies a prolonged fast (Fig. 2). These data are consistent with a previous report that, when circulating insulin is reduced after streptozotocin administration, POMC gene expression in the ARC is reduced, and the administration of insulin systemically restores POMC expression (Kim et al., 1999). However, it could not be concluded from that report whether insulin or leptin was the key factor because streptozotocin treatment also results in reduced circulating leptin, and systemic insulin administration leads to an immediate increase in plasma leptin. The current results indicate that the local administration of a small amount of insulin directly into the CNS stimulates POMC gene expression, presumably through the insulin receptors found on POMC neurons.

The observations that insulin receptors are expressed by POMC neurons and that insulin stimulates POMC gene expression suggest that insulin may reduce food intake and body weight by acting through the central melanocortin system. However, because the POMC precursor encodes a number of important ligands, the data from the first two experiments do not unambiguously relate insulin signaling to increased activity at melanocortin receptors. To this end, we determined the ability of melanocortin receptor antagonists to block the anorexic actions of centrally administered insulin. As illustrated in Figure 3, a nonspecific melanocortin 3/4 receptor antagonist, SHU-9119, was able to significantly attenuate the reduction in food intake elicited by insulin administration. Hence, like leptin, insulin appears to exert its central catabolic action by acting through melanocortin receptors.

Collectively, these experiments provide the first demonstration that the CNS melanocortin system is an important downstream target for the effects of insulin to regulate food intake and body weight. Therefore, they provide a significant step in delineating the critical pathways that allow for the maintenance of energy balance. The present data also indicate that one important role for the CNS melanocortin system is to integrate the message conveyed by insulin and leptin and likely other important signals, as well (Woods et al., 1998; Schwartz et al., 2000; Cowley et al., 2001).

\section{REFERENCES}

Bagdade JD, Bierman EL, Porte Jr D (1967) The significance of basal insulin levels in the evaluation of the insulin response to glucose in diabetic and nondiabetic subjects. J Clin Invest 46:1549-1557.

Barsh GS, Farooqi IS, O'Rahilly S (2000) Genetics of body-weight regulation. Nature 404:644-651.

Baskin DG, Porte DJ, Guest K, Dorsa DM (1983) Regional concentrations of insulin in the rat brain. Endocr J 112:898-903.

Baura G, Foster D, Porte Jr D, Kahn SE, Bergman RN, Cobelli C, Schwartz MW (1993) Saturable transport of insulin from plasma into 
the central nervous system of dogs in vivo: a mechanism for regulated insulin delivery to the brain. J Clin Invest 92:1824-1830.

Bjorbaek C, Elmquist JK, Frantz JD, Shoelson SE, Flier JS (1998) Identification of SOCS-3 as a potential mediator of central leptin resistance. Identification of SOCS-3 as a potential mediator of central leptin resistance. Mol Cell 1:619-625.

Brüning JC, Gautam D, Burks DJ, Gillette J, Schubert M, Orban PC, Klein R, Krone W, Müller-Wieland D, Kahn CR (2000) Role of brain insulin receptor in control of body weight and reproduction. Science 289:2122-2125.

Chavez M, Seeley RJ, Woods SC (1995) A comparison between the effects of intraventricular insulin and intraperitoneal $\mathrm{LiCl}$ on three measures sensitive to emetic agents. Behav Neurosci 109:547-550.

Cheung CC, Clifton DK, Steiner RA (1997) Proopiomelanocortin neurons are direct targets for leptin in the hypothalamus. Endocrinology 138:4489-4492.

Cowley MA, Smart JL, Rubinstein M, Cerdan MG, Diano S, Horvath TL, Cone RD, Low MJ (2001) Leptin activates anorexigenic POMC neurons through a neural network in the arcuate nucleus. Nature 411:480-484.

Emanuelli B, Peraldi P, Filloux C, Sawka-Verhelle D, Hilton D, Van Obberghen E (2000) SOCS-3 is an insulin-induced negative regulator of insulin signaling. J Biol Chem 275:15985-15991.

Fan W, Boston B, Kesterson R, Hruby V, Cone R (1997) Role of melanocortinergic neurons in feeding and the agouti obesity syndrome. Nature 385:165-168.

Hagan M, Rushing P, Schwartz M, Yagaloff K, Burn P, Woods S, Seeley R (1999) Role of the CNS melanocortin system in the response to overfeeding. J Neurosci 19:2362-2367.

Hagan MM, Rushing PA, Pritchard LM, Schwartz MW, Strack AM, Van der Ploeg HT, Woods SC, Seeley RJ (2000) Long-term orexigenic effects of AgRP-(83-132) involve mechanisms other than melanocortin receptor blockade. Am J Physiol 279:R47-R52.

Hunyady B, Krempels K, Harta G, Mezey E (1996) Immunohistochemical signal amplification by catalyzed reporter deposition and its application in double immunostaining. Immunohistochemical signal amplification by catalyzed reporter deposition and its application in double immunostaining. J Histochem Cytochem 44:1353-1362.

Huszar D, Lynch CA, Fairchild-Huntress V, Dunmore JH, Fang Q, Berkemeier LR, Gu W, Kesterson RA, Boston BA, Cone RD, Smith FJ, Campfield LA, Burn P, Lee F (1997) Targeted disruption of the melanocortin-4 receptor results in obesity in mice. Cell 88:131-141.

Kim EM, Grace MK, Welch CC, Billington CJ, Levine AS (1999) STZ-induced diabetes decreases and insulin normalizes POMC mRNA in arcuate nucleus and pituitary in rats. Am J Physiol 276: R1320-R1326.

McGowan MK, Andrews KM, Grossman SP (1992) Chronic intrahyphothalamic infusions of insulin or insulin antibodies alter body weight and food intake in the rat. Physol Behav 51:753-766.

Medhurst AD, Harrison DC, Read SJ, Campbell CA, Robbins MJ,
Pangalos MN (2000) The use of TaqMan RT-PCR assays for semiquantitative analysis of gene expression in CNS tissues and disease models. J Neurosci Methods 98:9-20.

Mizuno T, Kleopoulos S, Bergen H, Roberts J, Priest C, Mobbs C (1998) Hypothalamic pro-opiomelanocortin mRNA is reduced by fasting and in ob/ob and $\mathrm{db} / \mathrm{db}$ mice, but is stimulated by leptin. Diabetes 47:294-297.

Niswender KD, Morton GJ, Stearns WH, Rhodes CJ, Myers Jr MG, Schwartz MW (2001) Intracellular signalling. Key enzyme in leptininduced anorexia. Nature 413:794-795.

Ollmann M, Wilson B, Yang Y, Kerns J, Chen Y, Gantz I, Barsh G (1997) Antagonism of central melanocortin receptors in vitro and in vivo by agouti-related protein. Science 278:135-138.

Schwartz MW, Figlewicz DP, Baskin DG, Woods SC, Porte Jr D (1992) Insulin in the brain: a hormonal regulator of energy balance. Endocr Rev 13:387-414.

Schwartz MW, Seeley RJ, Weigle DS, Burn P, Campfield LA, Baskin DG (1997) Leptin increases hypothalamic proopiomelanocoritin (POMC) mRNA expression in the rostral arcuate nucleus. Diabetes 46:2119-2123.

Schwartz MW, Woods SC, Porte DJ, Seeley RJ, Baskin DG (2000) Central nervous system control of food intake. Nature 404:661-671.

Seeley RJ, Yagaloff KA, Fisher SL, Burn P, Thiele TE, van Dijk D, Baskin DG, Schwartz MW (1997) Melanocortin receptors in leptin effects. Nature 390:349.

Stubdal H, Lynch CA, Moriarty A, Fang Q, Chickering T, Deeds JD, Fairchild-Huntress V, Charlat O, Dunmore JH, Kleyn P, Huszar DK, R (2000) Targeted deletion of the tub mouse obesity gene reveals that tubby is a loss-of-function mutation. Mol Cell Biol 20:878-882.

Thiele T, van DG, Yagaloff K, Fisher S, Schwartz M, Burn P, Seeley R (1998) Central infusion of melanocortin agonist MTII in rats: assessment of c-Fos expression and taste aversion. Am J Physiol 274:R248-R254.

Thornton JE, Cheung CC, Clifton DK, Steiner RA (1997) Regulation of hypothalamic proopiomelanocortin mRNA by leptin in ob/ob mice. Endocrinology 138:5063-5067.

Watson Jr RE, Wiegand SJ, Clough RW, Hoffman GE (1986) Use of a cryoprotectant to maintain long-term peptide immunoreactivity and tissue morphology. Peptides 7:155-159.

Woods SC, Decke E, Vasselli JR (1974) Metabolic hormones and regulation of body weight. Psychol Rev 81:26-43.

Woods SC, Lotter EC, McKay LD, Porte Jr D (1979) Chronic intracerebroventricular infusion of insulin reduces food intake and body weight of baboons. Nature 282:503-505.

Woods SC, Seeley RJ, Porte DJ, Schwartz MW (1998) Signals that regulate food intake and energy homeostasis. Science 280:1378-1383.

Yaswen L, Diehl N, Brennan MB, Hochgeschwender U (1999) Obesity in the mouse model of pro-opiomelanocortin deficiency responds to peripheral melanocortin. Nat Med 5:1066-1070. 